\title{
Statyba
}

\section{INFLUENCE OF CHANGE OF COMPACTED SAND STRUCTURE ON THE DESIGN STRENGTH OF SUBSOIL}

\section{A. Alikonis}

To cite this article: A. Alikonis (1998) INFLUENCE OF CHANGE OF COMPACTED SAND STRUCTURE ON THE DESIGN STRENGTH OF SUBSOIL, Statyba, 4:4, 283-291, DOI: 10.1080/13921525.1998.10531419

To link to this article: https://doi.org/10.1080/13921525.1998.10531419

曲 Published online: 26 Jul 2012.

Submit your article to this journal $₫$

Џ Article views: 60

4 Citing articles: 1 View citing articles 지 


\section{ВЛИЯНИЕ ИЗМЕНЕНИЯ СТРУКТУРЫ ПЕСЧАНОГО ГРУНТА ПРИ ЕГО УПЛОТНЕНИИ НА РАСЧЕТНОЕ СОПРОТИВЛЕНИЕ ОСНОВАНИЙ ЗДАНИЙ}

\section{А. Аликонис}

\section{1. Введение}

Изменение структуры песчаного грунта при его уплотнении заметно влияет на его деформационные свойства. Уплотненные до высокой степени плотности рыхлые или средней плотности песчаные грунты, что обычно имеет место при устройстве фундаментов в вытрамбованных котлованах [1, 2, 3, 4] или при планомерно возведенных насыпях и песчаных подушках под фундаментами [5], улучшают деформационные свойства. При уплотнении песчаного грунта сближаются его частицы, формируются новые контактные связи между ними. Степень сближения частиц грунта зависит от состояния грунта и его вида, характера механического воздействия на грунт. Способность естественного песчаного грунта уплотняться, особенно при устройстве фундаментов в вытрамбованных котлованах, можно оценить по результатам статического зондирования $[6,7]$.

Необходимая степень уплотнения грунта в насыпях и песчаных подушках под фундаментами задается в проектах сооружений с обязательным указанием значений плотности сухого грунта. Контроль качества работ по укладке и уплотнению грунта ведется систематически представителями технического надзора. Качество уплотнения и степень влажности грунта периодически проверяются и сопоставляются с проектом и техническими условиями. Иногда по результатам контроля качества уплотнения корректируется и уточняется расчетное сопротивление грунта как основания проектируемого здания.

В результате уплотнения песчаного грунта разрушаются природные структурные связи между отдельными частицами и агрегатами, однако увеличивается плотность, угол внутреннего трения и модуль деформации по сравнению с природными значениями.
Уплотненная зона, в которой изменена естественная структура грунта, создается в котлованах, полученных способом трамбования. Расчет оснований фундаментов в вытрамбованных котлованах с уплотненной зоной по деформациям производят с учетом плотности и прочностных характеристик уплотненного слоя, его толшины, a также величины расчетного давления грунта, залегающего ниже уплотненного слоя $[8,9]$.

За расчетное сопротивление основания фундамента в вытрамбованном котловане принимают минимальное значение давления, которое получают из следуюших условий [10]:

1) расчетное сопротивление основания на уплотненный грунт $R_{1}$ (по СНиП 2.02.01-83 [11] и с использованием прочностных характеристик $\varphi_{\text {" }}$ и $C_{\text {, }}$;

2) расчетное сопротивление основания $R_{2}$, определяемое, исходя из давления на подстилающий уплотненную зону грунт естественного сложения или другой слой грунта.

Осадки фундаментов в вытрамбованных котлованах с уплотненной зоной определяют по схеме двухслойного основания, состояшего из уплотненного слоя, в котором грунт имеет нарушенное сложение, и подстилающего естественного грунта.

При расчете оснований фундаментов в вытрамбованньх котлованах по выше приведенной методике сталкиваемся с болышими трудностями: заранее неизвестны характеристики будущего уплотненного грунта и его плотность. Они определяются по опытным работам по вытрамбованию котлованов или принимаются по рекомендациям [8].

Проще оценить изменение структуры песчаного грунта в основаниях фундаментов в вытрамбованных котлованах и его влияние на расчетное сопротивление грунта можно по зави- 
симостям между свойствами уплотненного грунта и результатами статического зондирования песчаного грунта естественного сложения на месте будушей строительной плошадки. Для получения и анализа упомянутых зависимостей проводились экспериментальные исследования работы фундаментов в вытрамбованных котлованах в песчаных грунтах и лабораторные исследования физикомеханических свойств, исследования статическим зондированием в натуральных условиях залегания грунта, а также обобщался опыт строительства в Литве.

\section{2. Изменение коэффициента пористости при} уплотнении песчаного грунта и его оценка статическим зондированием

Or значения пористости зависят сжимаемость, водопроницаемость и некоторые другие свойства грунтов. Численные значения коэффициента пористости используют при определении сжимаемости грунтов, условных расчетных давлений на основания, степени уплотняемости и др. В зависимости от значений коэффициента пористости $е$ можно оценить плотность сложения песков [12].

Коэффициент пористости в зависимости от значений плотности частиц $\rho_{s}$ и плотности сухого грунта $\rho_{d}$ вычисляют по формуле:

$$
e=\frac{\rho_{s}}{\rho_{d}}-1
$$

В работе [13] для определения плотности сухого грунта при уплотнении предлагается формула:

$$
\rho_{\text {дупл }}=\frac{\rho_{s}(1-0,01 v)}{1+\rho_{s} w_{0} 0,01},
$$

где $\rho_{s}-$ плотность частиц грунта

$w_{0}$ - оптимальная влажность в \%;

$v$ - объем воздуха в грунте при оптимальной влажности в \%.

Однако применение формулы (2) для расчета плотности сухого грунта при его уплотнении для песчаного грунта затрудняется из-за неточного определения количества воздуха в его порах.

Руководство по проектированию и устройству фундаментов в вытрамбованных котлованах [8] рекомендует среднее значение плотности сухого грунта в пределах уплотняемой зоны определять по формуле:

$$
\rho_{\text {dyпл }}=\frac{1}{2}\left(\rho_{d}+\frac{s_{r} \rho_{s} \rho_{w}}{s_{r} \rho_{w}+w \rho_{s}}\right),
$$

где $\rho_{d}$ - среднее значение плотности сухого грунта естественного сложения в пределах слоя от отметки вытрамбования до нижней границы углотняемой зоны;

$s_{r}$ - степень влажности уплотненного грунта, принимая ее равной 0,9 ;

$w$ - влажность грунта в долях единицы;

$\rho_{w}$-плотность воды, принимаемая равной 1.

Принимая $s_{r}=1$ и подставляя в формулу (2), получаем:

$$
\rho_{\mathrm{dyII}}=\frac{1}{2}\left(\rho_{d}+\frac{\rho_{s}}{1+w \rho_{s}}\right) .
$$

Анализ расчетных значений плотности сухого грунта по формулам (2) и (3) и экспериментальных результатов, определения плотности сухого грунта в лабораторных условиях показал, что для сухих и маловлажных грунтов они дают приближенные результаты. Поэтому для определения возможной плотности сухого грунта при уплотнении установить ее максимаґьное значение следует по лабораторным исследованиям, принимая коэффициент уплотнения, равным единице.

Подставляя значение плотности сухого грунта $\rho_{\text {дупл }}$ в формулу (1), получаем выражение для расчета коэффициента пористости уплотненного грунта:

$$
e_{\text {упл }}=\left(\rho_{s} / \rho_{\text {дупл }}\right)-1
$$

В [14] для расчета значений коэффициента пористости по результатам статического зондирования песчаных грунтов предлагается следующая формула:

$$
e=2,8 \gamma h / \ln q_{c}
$$

где $\gamma$ - удельный вес грунта;

$h$ - глубина зондирования;

$q_{c}$ - сопротивление погружению конуса.

Сравнение значений коэффициента пористости, полученных по формуле (6) и в результате экспериментальных исследований, показало, что 
для глубины зондирования до 1,5 м (это соответствует глубине заложения испытанных нами фундаментов в вытрамбованных котлованах) эта формула дает не совсем точные результаты. Удовлетворительные результаты получаются по формуле (6) для небольшой глубины зондирования, однако без учета удельного веса грунта и глубины зондирования.

Как показали наши исследования, хорошо совпадающие с экспериментальными данными в соответствующих пределах результаты получаем при расчете коэффициента пористости от сопротивления погружению конуса при статическом зондировании для песчаных грунтов по формуJIe [15]:

$$
e=0,765-0,185 \lg \left(q_{s} / q_{s}^{0}\right),
$$

где $q_{s}^{0}-1 \mathrm{M \Pi а.}$

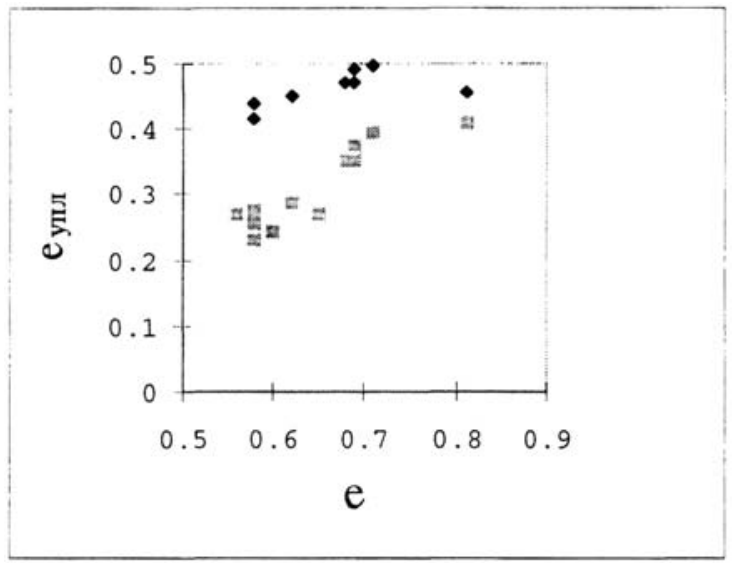

Рис. 1. Зависимость коэффициента пористости уплотненного мелкого песка $e_{\text {упл }}$ от коэффициента пористости естественного сложения $e$. - получена в результате экспериментов; $\mathrm{x}$ - по расчету (формула (5))

Fig 1. Corelation between void ratio natural fine sand and void ratio compacted fine sand. - experimental; $\mathrm{x}$ calculated

Используя результаты исследования физинеских свойств песчаного грунта естественного сложения по формулам (1) и (5), можно рассчитать коэффициенты пористости естественного и уплотненного песганого грунта, принимая $\rho_{s}=2,65 \mathrm{r} / \mathrm{cm}^{3}$.

На рис. 1 показана зависимость коэффициента пористости уплотненного мелкого песка, определенного по формуле (5), от коэффициента пористости того же песка естественного сложения, исследования которого проводились в лаборатории и в натурапьных условиях залегания грунта статическим зондированием.

Из рис. 1 видно, что коэффициенты пористости уплотненного мелкого песка, рассчитанные в зависимости от значений плотности сухого грунта, определенных по формуле (3), не совпадают с коэффициентами пористости, полученными по результатам экспериментальных исследований плотности сухого грунта в натураљьных условиях залегания уплотненного грунта. Очевидно, что для прогнозирования плотности песчаного грунта после его уплотнения, как уже говорилось выше, следует пользоваться возможными максимальными значениями плотности сухого грунта, определенными лабораторными исследованиями естественного грунта при коэффициенте уплотнения, равном единице.

По коэффициенту пористости уплотненного песчаного грунта можно приближенно прогнозировать, как изменится плотность грунта естественного сложения при уплотнении.

Формула (6) для расчета коэффициента пористости песчаного грунта по результатам статического зондирования может быть использована для определения сопротивления погружению конуса зонда при соответствуюшем значении коэффициента пористости без учета плотности грунта и глубины зондирования

$$
\ln \mathrm{q}_{\mathrm{c}}=2.8 / \mathrm{e} \text {. }
$$

На рис. 2 показана зависимость сопротивления погружению конуса при статическом зондировании от коэффициента пористости песка.

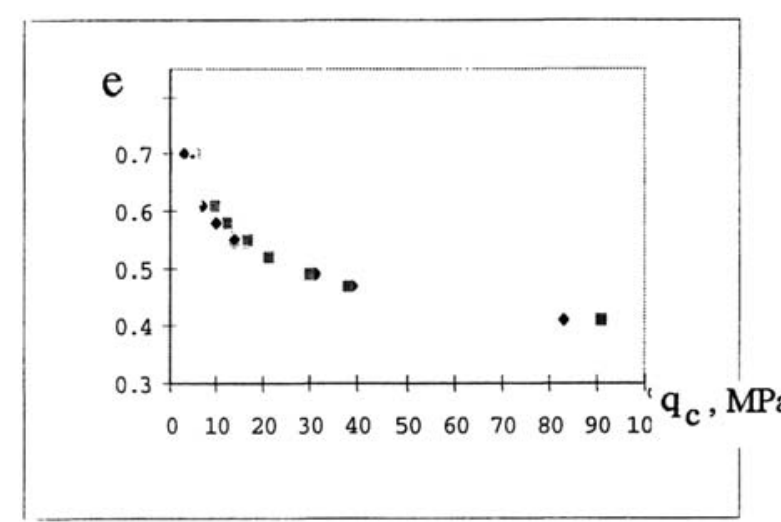

Рис. 2. Зависимость сопротивления погружению конуса от коэффициента пористости: - - экспериментальные для мелкого песка; - по формуле (7), х рассчитанных по формуле (8)

Fig 2. Correlation between tip resistance CPT and void ratio. $\mathrm{x}$ - calculated according to (8); - experimental; $\bullet$ calculated according to (7) 
Из рис. 2 видно, что экспериментально определенные значения зависимости сопротивления погружению конуса от коэффициента пористости почти совпадают с рассчитанными по формулам (7) и (8).

В работе [16] представлены графики для определения расчетного сопротивления основания буронабивных фундаментов в зависимости от сопротивления погружению конуса при статическом зондировании песчаных грунтов.

За расчетное сопротивление основания принято давление на грунт под подошвой фундамента, вызывағощее осадку в $0.5,1,2$ или 3\% от диаметра фундамента [16]. Какой процент от диаметра фундамента должна составить осадка, определяет специалист, проектируюший здание или сооружение. При отсутствии графиков расчетное сопротивление основания буробетонного фундамента предлагается рассчитывать по формуле:

$$
\begin{gathered}
R_{s n} \cong 0,03 n q_{c}, \\
n=100 \frac{s}{D},
\end{gathered}
$$

где $s$ - осадка фундамента;

$D$ - диаметр фундамента.

Работа фундаментов в вытрамбованных котлованах цилиндрической формы отличается от работы в буронабивных фундаментах тем, что первые имеют основание из грунта нарушенного сложения и уплотненного при вытрамбовании котлована, а буронабивные имеют основание из естественного грунта. Принимая расчетное сопротивление основания фундамента в вытрамбованном котловане аналогично сопротивлению буронабивного фундамента [16], т. е. давление на грунт под подошвой фундамента, вызываюшее n-процентную осацку, приблизительно расчетное сопротивление основания можно определить по графикам [16] или по формуле (9).

С этой целью сопротивление погружению конуса при статическом зондировании уплотненного основания фундамента в вытрамбованном котловане определяем, исходя из зависимостей (5), (7) ити (8) .

По проанализированной выше методике можно приблизительно определить расчетное сопротивление уплотненного песчаного основания фундамента в вытрамбованном котловане цилиндрической формы. Работа фундамента в вытрамбованном в форме усеченной пирамиды котловане отличается от таковой в котловане цилиндрической формы.

\section{3. Экспериментальные исследования работы уп-} лотненного основания фундаментов в котлованах, вытрамбованньх в виде усеченной пирамиды

Столбчатые фундаменты, возведенные в котлованах, полученных вытрамбованием, имеют повышенную несушую способность по сравнению с возведенными в выкопанных котлованах. Кроме того, при этом достигается экономия материаљных и энергетических ресурсов, так как отсутствует разработка грунта экскаватором, транспортировка грунта, обратная засыпка котлованов, опалубочные работы при бетонировании фундаментов. Практика строительства показывает, что метод возведения фундаментов в вытрамбованных котлованах может успешно применяться на грунтах многих видов $[1,16]$.

С целью определения влияния уплотненной зоны песчаного грунта под фундаментом в вытрамбованных котлованах на расчетное сопротивление основания проводилась серия опытов. Испытанию подвергались фундаменты в вытрамбованных котлованах и фундаменты тех же размеров в котлованах, вырытых вручную $[17,18$, 19]. Основанием фундаментов служили рыхлые и средней плотности мелкозернистые пески в натуральных условиях залегания.

Фундаменты имели форму усеченной пирамиды размером по подошве $0,6 \times 0,6$ м и по верху $0,7 \times 0,7$ м, высотой 1,2 м. Вытрамбование производилось трамбовкой-штампом массой 1,2 т, сбрасываемым с высоты 3,0 м. Для образования котлованов потребовалось произвести 17-30 ударов в одно место [20].

Результаты испытаний показывают (рис. 3 и 4), что работа фундаментов в вытрамбованньхх котлованах резко отличается от работы фундаментов в вырытых котлованах. Графики нагрузка -осадка совпадают лишь в начаљьой стадии нагружения (25-300 kN). Далее с увеличением нагрузки осадка фундаментов в вытрамбованных котлованах оказывается в прямолинейной зависимости от нагрузки, а осадка фундаментов, возведенных в естественном грунте, - в криволинейной зависимости. 


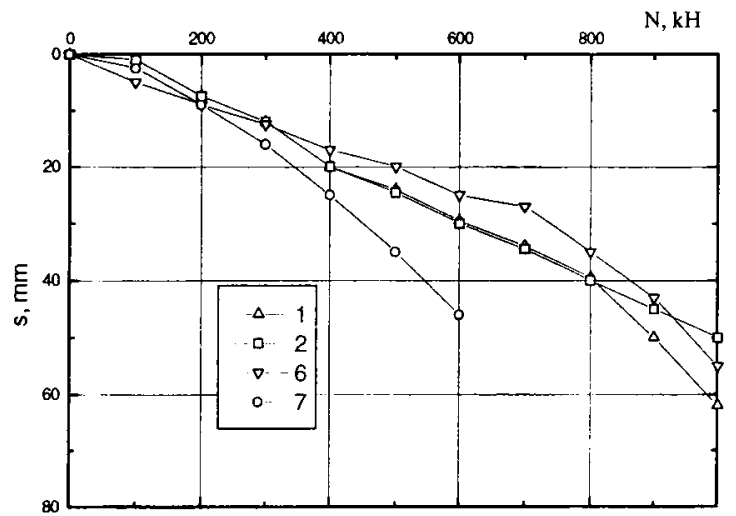

Рис. 3. Зависимость осадки от нагрузки фундаментов в вытрамбованных котлованах

Fig 3. Dependence between the loads and settlements of the foundations in tampered pits

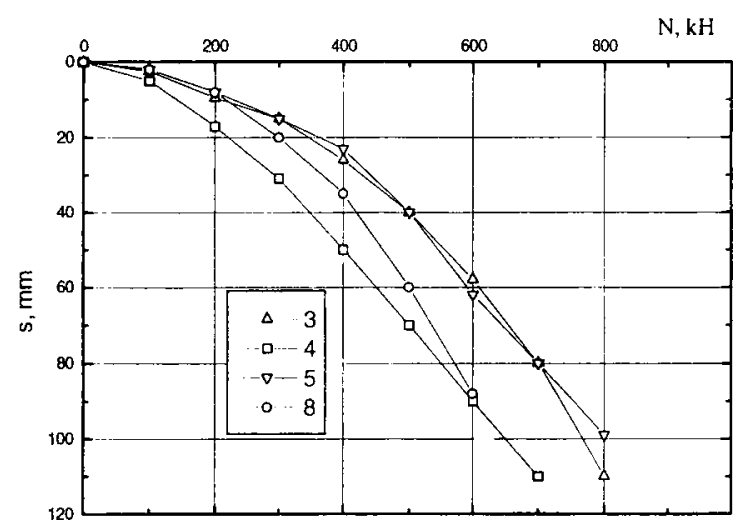

Рис. 4. Зависимость осадки от нагрузки фундаментов в выкопанных котлованах

Fig 4. Dependence between the loads and settlements of the foundations in dug pits

Если нагрузку, вызвавшую осадку величиной 0,1 D (D - ширина фундамента), принять за предельную, получим, что несущая способность фундамента в вытрамбованном котловане почти в два раза больше, чем таковая фундаментов, возведенных на естественном основании. Предельная несущая способность фундаментов в вытрамбованных котлованах составила 900-1100 $\mathrm{kH}$, а фундаментов на естественном основании - 500-600 кH.

Для исследования распределения нагрузки по подошве и боковым поверхностям фундамента на дно котлована перед бетонированием укладывали металлическую плиту размером $60 \times 60 \times 2 \mathrm{~cm}$, на которой устанавливали три тензометра ДЭДВУ-20. Сверху укладывали металлическую плиту толщиной 1 см и бетонировали фундамент.
Результаты исследования [21, 22] показали, что фундамент в вытрамбованном котловане до нагрузки $300 \mathrm{kH}$ передает эту нагрузку через подошву на основание и на грунт по боковой поверхности. В интервалах нагрузок 300-700 кH нагрузку принимает подошва фундамента, а при нагрузке $700 \mathrm{\kappa H}$ увеличивается доля нагрузки на боковую поверхность фундамента и уменьшается на подошву.

Экспериментальые исследования изменения плотности песчаного грунта вокруг фундамента в вытрамбованном котловане [23] показали, что, кроме уплотненной зоны, которая зафиксирована и в других работах $[8,9,24]$, замечены зоны грунта, разрыхленного до глубины 0,3 м от поверхности.

Часть нагрузки на фундамент в форме усеченной пирамиды в вытрамбованном котловане передается на грунт по боковой поверхности. Для определения этой нагрузки предлагается несколько методов.

Анализ экспериментальных и расчетных результатов $[20,21]$ показал, что для расчета нагрузки, передаваемой на грунт по боковой поверхности, для исследованных песчаных грунтов наиболее приемлема методика, рекомендованная в $[22,25]$.

Принимая за расчетное сопротивление основания нагрузку, вызывающую осадку фундамента в $0,02 \mathrm{D}$ (D - диаметр или сторона фундамента), по результатам экспериментальных исследований для фундамента в вытрамбованном котловане в виде усеченной пирамиды, получаем

$$
R_{s 2}=0,09 q_{c}
$$

где $q_{c}$ - сопротивление погружению конуса при статическом зондировании естественного грунта.

Соответственно получаем эмпирические выражения для приближенного определения расчетного сопротивления основания при $s=0,01 D$ :

$$
R_{s 1}=0,05 q_{c} \text {, }
$$

при $n=0,03 D$

$$
R_{s 3}=0,13 q_{c} .
$$

Фундаменты в виде усеченной пирамиды в вытрамбованных котлованах нагрузку на основание передают через подошву и боковую поверх- 
ность. При соответствующей нагрузке доля нагрузки на боковую поверхность увеличивается по сравнению с нагрузкой на подошву [21]. Поэтому при случайных повреждениях грунта в боковом пространстве фундамента резко уменьшается его несушая способность. Менее чувствительны к такому повреждению фундаменты цилиндрической формы в вытрамбованных котлованах.

Строители Литвы отдают предпочтение фундаментам цилиндрической формы в вытрамбованных котлованах. В основании этих фундаментов по-другому формируются уплотненные зоны, нет распора грунта по боковым поверхностям.

4. Экспериментальное исследование работы уплотненного основания фундаментов цилиндрической формы в вытрамбованных котлованах

Для исследования работы уплотненного вытрамбованием котлованов основания фундаментов цилиндрической формы были испытаны статической нагрузкой шесть фундаментов: два фундамента в песке средней крупности с сопротивлением погружению конуса при статическом зондировании в 4MПа (опыт 1 и 2) и четыре фундамента в мелкозернистом песке с сопротивлением погружению конуса при статическом зондировании в 4, 5, 8 и 8 МПа (опыты 3, 4, 5, 6). Фундаменты были монолитными, диаметр которых 1 м и глубина залегания 2 м [26].

При обработке результатов исследований отдельно по методике [16] определялась нагрузка, передаваемая по боковой поверхности. Остальная часть нагрузки передавалась основанию через подошву фундамента. По зависимости осадки фундамента от нагрузки находим значения напряжений $\sigma$, при которых отношение осадки $s$ к диаметру $D$ составляет $0,5,1,2$ и $3 \%$, что соответствует по формуле (10) $n=0,5,1,2,3$.

Величина напряжений в плоскости подошвы фундамента, вызывающих $n$-процентную осадку фундамента, которую принимаем за расчетное сопротивление основания, определяется по формуле [2]:

$$
\sigma_{n}=\frac{\alpha}{\omega\left(1-v^{2}\right)} n q_{c},
$$

где $\alpha$ - коэффициент пропорциональности при определении модуля деформащии грунта по значению сопротивления грунта погружению конуса при статическом зондировании;

$\omega$ - коэффициент формы фундамента, принимаемый для круглого фундамента равным 0,67 ;

$v$ - коэффициент поперечной деформации, принимаемый для песков равнњп 0,3;

$q$ - сопротивление естественного грунта погружению конуса при статическом зондировании.

Формула (14) показывает, что при заданном процентном отношении осадки $\mathrm{k}$ диаметру между напряжениями, вызывающими $n$-процентную относительную осадку, и сопротивлением грунта погружению конуса при статическом зондировании существует прямолинейная зависимость. По полученной зависимости (14) составлялись графики и рассчитывались параметры уравнения регрессии зависимости между напряжениями и сопротивлением грунта погружению конуса при статическом зондировании. Хорошие результаты получаются при использовании следующего выражения:

$$
\sigma_{n}=\left(0,231 q_{c}+0,342 n\right) \operatorname{th}(0,585 n) .
$$

Обозначения в формуле (15) те же, что и в формуле (14). Напржжение $\sigma_{n}$, рассчитанное по формуле (15), принимается за расчетное сопротивление основания $R_{s n}$ при соответствующей $n$.

В зависимостиі от расчетного сопротивления уплотненного основания $R_{s n}$ и сопротивления погружению конуса при статическом зондировании естественного грунта можно рассчитать коэффициенты перехода $\alpha$ для расчета $R_{s n}$ от $q_{c}$ при заданном $n$. Результаты расчета представлены в таблице.

По данным таблицы получим упрощенную формулу для предварительного определения расчетного сопротивления уплотненного основания фундамента в вытрамбованном котловане по сопротивлению погружению конуса при статическом зондировании естественного песчаного грунта:

$$
R_{s n}=0,16 n q_{c} .
$$

Расчетное сопротивление основания фундаментов цилиндрической формы на естественном песчаном грунте приблизительно определяется 
Коэффициенты $\alpha$ для расчета $R_{s n}$ по $q_{c}$ (по формуле (15))

Factor $\alpha$ values for $R_{s n}$ calculated according to formula (15)

\begin{tabular}{|c|c|c|c|}
\hline$n$ & $\alpha=R_{s n} / q_{c}$ & $\begin{array}{c}\text { Среднее } \\
\text { значение } \alpha\end{array}$ & $R_{s n}=\alpha n q_{c}$ \\
\hline 1 & $\begin{array}{l}0.21 \\
0.16 \\
0.15 \\
0.14\end{array}$ & 0.16 & $R_{s n}=0,16 n q_{c}$ \\
\hline 2 & $\begin{array}{l}0.47 \\
0.33 \\
0.28 \\
0.26\end{array}$ & 0.33 & $R_{s n}=0,16 n q_{c}$ \\
\hline 3 & $\begin{array}{l}0.70 \\
0.46 \\
0.38 \\
0.33\end{array}$ & 0.46 & $R_{s n}=0,15 n q_{c}$ \\
\hline
\end{tabular}

пормуле (9). Сравнение формул (16) и (9) показывает, что изменение структуры песчаного грунта при его уплотнении трамбованием котлованов цилиндрической формы увеличивает расчетное сопротивление основания $R_{s n}$ приблизительно в пять раз. По формулам (15) и (16) можно определить расчетное сопротивление уплотненного основания по результатам статического зондирования естественного песчаного грунта.

\section{4. Заключение}

Изменение структуры песчаного грунта при его уплотнении увеличивает значения модуля деформаций, плотности и прочностных свойств. Степень увеличения зависит от влажности, гранулометрического состава и других свойств грунта и, конечно, от характера механического воздействия на грунт.

Уплотненная зона, в которой изменяется естественная структура грунта, формируется в котлованах, полученных способом трамбования. Важно прогнозировать плотность будущего уплотненного грунта по данным исследования естественного грунта.

С этой целью следует определять максимальное значение плотности сухого грунта, рассчитывать коэффициент пористости будущего уплотненного грунта. Плотность частиц песчаного грунта изменяется в неболыших пределах, поэтому для инженерньг расчетов следует принимать среднее ее значение. Сопротивление погружению конуса при статическом зондировании можно определять по зависимости от коэффициента пористости. Данные о сопротивлении погружению конуса при статическом зондировании предоставляют возможность оценить уплотненное основание при проектировании оснований фундаментов зданий и сооружений. Принимая за расчетное сопротивление основания фундамента в вытрамбованном котловане напряжения в плоскости подошвы фундамента, вызываюшие $n$-процентную от диаметра фундамента осадку, и анализируя экспериментальные результаты, получили зависимости расчетного сопротивления от сопротивления погружению конуса при статическом зондировании естественного грунта. Следует подчеркнуть, что значения принятого нами расчетного сопротивления основания фундамента в вытрамбованном котловане цилиндрической формы на песчаном грунте отличаются от таковых для фундаментов в виде усеченной пирамиды.

Для испытанных нами фундаментов в виде усеченной пирамиды в среднем расчетное сопротивление основания будет следующим:

$$
R_{s n} \cong 0,4 n q_{c} \text {. }
$$

Для фундаментов цилиндрической формы коэффициент перехода $\alpha=0,16$ (формула (16)).

Разница в коэффициентах перехода получается из-за того, что фундаменты пирамидальной формы большую нагрузку принимают по боковой поверхности по сравнению с фундаментами цилиндрической формы. Для определения расчетного сопротивления основания фундамента в вытрамбованном котловане цилиндрической формы можно воспользоваться выражением (15), а для приблизительного расчета - формулой (16).

Изменение структуры песчаного грунта при его уплотнении на примере испытанных фундаментов в вытрамбованных котлованах увеличивает расчетное сопротивление основания примерно в пять раз. 


\section{Литература}

1. А. Аликонис. K вопросу о возведении фундаментов в вытрамбованных котлованах // Экономия ресурсов в строительстве с учетом местных материалов, конструкций и оснований. Тезисы докладов республиканской конференции. Вильнюс, 1985 , c. $76-77$.

2. A. Alikonis, J. Amšiejus. Plūktiniy pamatu tyrimai ir pagrindo skaičiuojamasis stiprumas // Statybinès konstrukcijos, Nr. 19. Vilniaus technikos universiteto mokslo darbai. Vilnius: Technika, 1993, p. 81-85.

3. А. Аликонис, И. Амшеюс. Расчетное сопротивление грунта основания фундамента в вытрамбованном котловане // Эффективные фундаменты, coоружаемые без выимки грунта. Сборник докладов республиканской научно-технической конференции. Полтава, 1991, с. 168-171.

4. А. Аликонис. Экспериментальные исследования фундаментов разного типа в вытрамбованньх котлованах // Прибалтийская геотехника VII. Тезисы докладов седьмой прибалтийско-белорусской конференции по инженерной геологии, механике грунтов и фундаментостроению. Рига, 1991, с. 9597.

5. А. Аликонис и др. Исследование песчаных подушек под железобетонными резервуарами // Геотехника III. Тезисы третьей республиканской конференции Эстонской, Латвийской и Литовской ССР по инженерной геологии, механике грунтов и фундаментостроению. Рига, 1975, с. 198-201.

6. A. Alikonis ir kt. Gruntu tanklumo tyrimai plūktinių pamatu statybai // Gelmiu geologinio tyrimo, naudojimo ir apsaugos problemos Lietuvoje. Vilnius, 1994, p. 141142.

7. A. Alikonis. Plüktinių pamatц pagrindo skaičiavimo klausimu // Тезисы конференции "Совершенствование строительной индустрии Литовской ССР”. Вильнюс, 1989, с. 52-53.

8. Руководство по проектированию и устройству фундаментов в вытрамбованных котлованах. Москва: Стройиздат, $1981.56 \mathrm{c}$.

9. В. И. Крутов и др. Фундаменты в вытрамбованньх котлованах. Москва: Стройиздат, 1985. $163 \mathrm{c}$.

10. В. И. Крутов. Основания и фундаменты на насыпных грунтах. Москва: Стройиздат, 1988.73 с.

11. СНиП 2.02.01-83. Основания зданий и сооружений. Москва: Стройиздат, 1985. 38c.

12. Основания и фундаменты. Справочник. Москва: Высшая школа, 1991. 21 с.

13. Справочное пособие по механизированному уплотнению грунтов. Москва: Стройиздат, 1965. 29 с.

14. Ю. Г. Трофименков, Л. Н. Воробков. Полевые методы исследования строительных свойств грунтов. Москва: Стройиздат, 1981. $108 \mathrm{c}$.

15. Л. Г. Мариупольский. Исследования грунтов для проектирования и строительства свайных фундаментов. Москва: Стройиздат, 1989. 57 с.

16. A. Alikonis ir kt. Monolitiniai grunte betonuojami pamatai. Vilnius: Mokslas, $1985.113 \mathrm{p}$.

17. А. Аликонис. Резервы несущей способности фундаментов в вытрамбованных котлованах // Тезисы конференции "Резервы научно-технического прогресса в строительстве республики". Вильнюс, 1987, c. $41-42$.
18. A. Alikonis ir kt. Eksperimentiniai išplūktose duobèse statomy pamaty tyrimai // Statybinès konstrukcijos. Lietuvos TSR Aukštujų mokyklų mokslo darbai. Vilnius: Mokslas, 1983, p. 21-26.

19. А. Аликонис и др. Исследование работы основания фундаментов в вытрамбованньх котлованах // Прибалтийская геотехника VI. Тезисы шестой прибалтийско-белорусской конференции по геотехнике. Таллин, 1986, с. 157-160.

20. A. Alikonis. Plūktinių pamatų ịrengimo galimybès smèliniuose gruntuose // 4-osios tarptautinès konferencijos "Naujos statybines medžiagos, konstrukcijos ir technologijos", îvykusios Vilniuje $1995 \mathrm{~m}$. gegužès 10-13 d., straipsniai. T. 1. Vilnius: Technika, 1995, p. 244-248.

21. А. Аликонис и др. Экспериментальные исследования фундаментов в вытрамбованных котлованах // Ускорение научно-технического прогресса в фундаментостроении. Т. II. Москва: Стройиздат, 1987, c. $177-178$

22. A. Alikonis. Piramidinių plūktinių pamatų šonų laikomosios galios skaičiavimas // Statybinès konstrukcijos, Nr. 20. Vilniaus technikos universiteto mokslo darbai. Vilnius: Technika, 1995, p. 31-35.

23. A. Alikonis, R. Mivydas. Sutankinto grunto prie plūktinio pamato eksperimentinis tyrimas // Statybinès konstrukcijos, Nr. 20. Vilniaus technikos universiteto mokslo darbai. Vilnius: Technika, 1995, p. 53-61.

24. М. Л. Зоценко. Напруженно-деформований стан основ фундаментів, якіспоруджують без виймання грунту. Автореферат дисертаці на здобуття наукового ступеня доктора технічних наук. Киів, 1994. $45 \mathrm{c}$.

25. A. Alikonis. Plūktiniu pamaty šony laikomoji galia // 3-osios tarptautines konferencijos "Naujos statybines medžiagos, konstrukcijos ir technologijos" straipsniai. Vilnius: Technika, 1993, p. 271-276.

26. A. Alikonis, J. Amšiejus. Plūktinių pamaty pagrindo skaičiuojamasis stiprumas // Geotechnika'91. Konferencijos darbai. Vilnius, 1991, p. 23-26.

İteikta 19980428

\section{SUTANKINTO SME்LINIO GRUNTO STRUKTŪROS PASIKEITIMO IৃTAKA PASTATO PAGRINDO PROJEKTINIAM STIPRUMUI}

\section{A. Alikonis}

\section{S a n $\mathrm{t}$ a u k a}

Smèlinio grunto struktūros pakeitimas ji tankinant padidina deformacijų modulio, tankio ir stiprumo reikšmes. Jụ padidejimas priklauso nuo drègnio, granuliometrinès sudèties ir kitu savybių bei nuo mechaninio poveikio gruntui. Sutankinta zona, kurioje pasikeičia natūrali grunto struktūra, formuojasi ir išplūkiant pamatų duobes. Svarbu prognozuoti büsimo sutankinto grunto tanki pagal natūralaus grunto fizikines ir mechanines savybes. Tam reikia nustatyti galimą maksimalią sauso grunto tankio reikšmę ir apskaičiuoti būsimo sutankinto grunto poringumo koeficientą. Smèlinio grunto daleliy tankio kitimo ribos nedideles, todèl inžineriniams apskaičiavimams galima naudoti jo vidutinę reikšmę. 
Grunto kūginị stiprumą statiškai zonduojant smèlinius gruntus galima apskaičiuoti pagal kūginio stiprumo priklausomybę nuo poringumo koeficiento (7), (8). Turint grunto kūgini stiprumą, gautą statiškai zonduojant gruntą, galima ivvertinti sutankintą pagrindą ir projektuoti pastatų bei statiniu pagrindus ir pamatus.

Laikydami, kad pamato išplūktoje duobeje pagrindo projektinis stiprumas yra jitempimai, kuriems esant pamatas nuseda nuo 1 iki 3\% pamato skersmens, ir analizuodami natūralių pamatų bandymų rezultatus, gavome pamato pagrindo projektinio stiprumo priklausomybę nuo natūralaus grunto kūginio stiprumo.

Mūsų taikyto pamatu išplūktose duobèse projektinio pagrindo stiprumo reikšmès skiriasi esant piramidiniam ir cilindriniam pamatui.

Piramidinio pamato pagrindo projektinis stiprumas pagal eksperimentinius natūraliụ pamaty tyrimus ir natūralaus grunto kūginį stiprumą statiškai zonduojant yra:

$$
R_{s n}=0,04 n q_{c} .
$$

Cilindrinio pamato pagrindo projektinis stiprumas pagal pamatụ bandymo rezultatus ir natūralaus grunto kūginị stiprumą statiškai zonduojant yra:

$$
R_{s n}=0,16 n q_{c} .
$$

Tai rodo, kad projektinis pagrindo stiprumas, esant cilindriniams pamatams išplūktose duobèse sméliniame grunte, yra daug didesnis už piramidinių pamatų pagrindo projektini stiprumą. Taip yra todel, kad piramidiniai pamatai didesnę apkrovos dali perima šonais, palyginti su cilindriniais pamatais.

Pagal gautas priklausomybes (formulès (15), (16), (17)) galima apskaičiuoti pamatų išplūktose duobèse pagrindo projektinị stiprumą.

Smèlinio grunto struktūros pakeitimas tankinant ji plūkiant pamatu duobes, padidina projektini pagrindo stiprumą iki penkių kartų.

\section{INFLUENCE OF CHANGE OF COMPACTED SAND STRUCTURE ON THE DESIGN STRENGTH OF SUBSOIL}

\section{A. Alikonis}

\section{S u m m a r y}

The values of deformation modulus and strength properties of subsoil increases during compaction. The increase depends on the content, grading of the soil, mechanical influence on the soil and other properties. The influenced space with changed soil properties may be formed by tamping the pits for the foundation. It is very important by using physical and mechanical properties of natural soil to forecast the density of compacted soil. For this purpose we have to determine the maximum density value of dry soil and calculate the void ratio of the compacted soil. Change of sand soil density is low. Thus its mean value is commonly used in engineering calculations.

The tip resistance CPT of sand can be calculated according to correlation between tip resistance CPT and void ratio (7), (8). When tip resistance CPT is obtained, it is possible to calculate the bearing capacity of the compacted subsoil and to design the foundation.

The assumption is made, that the design bearing capacity of foundation installed in the tampered pits is equal to the stresses in the subsoil when the settlement of the foundation is equal to $1 . . .3 \%$ of the foundation diameter. According to the tests, the correlation between tip resistance CPT and the bearing capacity of subsoil was made. It should be pointed out that the design bearing capacity of the foundations in the tampered pits are different depending on the shape of foundation.

Design bearing capacity of the pyramidal foundations according to the tests results:

$$
R_{s n}=0,04 n q_{c} .
$$

Design bearing capacity of the cylindrical foundations according to the tests results:

$$
R_{s n}=0,16 n q_{c} .
$$

It is obvious that bearing capacity of the cylindrical shape foundation installed in tampered pits of sandy soil is bigger than the pyramidal one. The reason is that the main part of the bearing capacity of pyramidal shape foundation is realised by the foundation side bearing capacity. The foundation side bearing capacity of the cylindrical shape foundation is smaller.

Design bearing capacity of the foundation in tampered pits may be calculated according to the equations (15), (16), (18). The value of the bearing capacity of the sandy subsoil may be increased up to five times by tampering the pits.

Antanas ALIKONIS. Doctor, Associate Professor. Dept of Geotechnics. Vilnius Gediminas Technical University. Sauletekio al. 11, 2040 Vilnius, Lithuania.

Doctor (technical sciences 1968). Dept of Foundation Engineering. In 1980-96 Head of Dept of Foundations (now Dept of Geotechnics). Research visits to Moscow and Dnepropetrovsk. Author and co-author of 3 monographs, over 100 scientific articles, 2 patents, 5 inventions and 14 study guides. Research interests: physical and mechanical properties of soil. 